Nig. J. Biotech. Vol. 33 (2017) 1-10

ISSN: 01891731

Available online at

http://www.ajol.info/index.php/njb/index

and www.biotechsocietynigeria.org

DOI: https://dx.doi.org/10.4314/v33i1.1

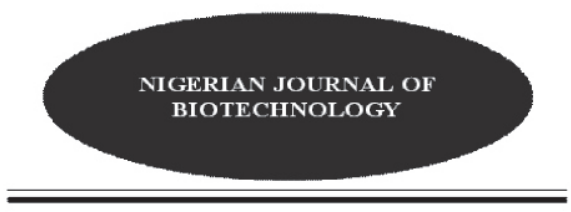

\title{
Screening of endophytic plant growth-promoting bacteria isolated from two Nigerian rice varieties. \\ Olayemi, $\mathbf{0}$. P. and Odedara, 0.0 . \\ Department of Microbiology, Federal University of Agriculture, Abeokuta, Nigeria. \\ (Received: 21:03:2017; Accepted:22 :06:2017)
}

\author{
Copyright resides with the authors in terms of the Creative Commons License 4.0. \\ See http://creativecommons.org/licenses/by/4.0/ \\ Condition of use: The user may copy, distribute, transmit and adapt the work, but must recognize the authors \\ and the Nigerian Journal of Biotechnology
}

\begin{abstract}
Probiotic bacteria, inhabiting the endosphere of plants, presents a major opportunity to develop cheap and eco-friendly alternatives to synthetic agrochemicals. Using standard microbiological procedures, culturable bacteria were isolated from the endosphere (root, stem and leaf) of two Nigerian rice varieties (Ofada and ITA 150). Assays including indole acetic acid (IAA) production, phosphate solubilization, seed germination assay, hydrogen cyanide (HCN) and ammonia production, and antifungal assay were conducted to identify the phytobeneficial bacterial strains. A total of 193 bacteria were isolated from all samples. The roots had the highest bacterial count of 45 and $61 \times 10^{8} \mathrm{cfu} / \mathrm{g}$ in Ofada and ITA 150 respectively when compared with the stem and leaf samples. The bacterial genera isolated were Bacillus, Pseudomonas, Enterobacter, Klebsiella, Staphylococcus, Citrobacter and Escherichia. Eight isolates produced IAA as well as ammonia. Phosphate solubilization was observed in five isolates while four isolates produced HCN. The germination rate of rice seeds coated with bacterial isolates ranged from $81.48 \%$ to $100 \%$. Eight bacterial isolates inhibited the growth of Fusarium oxysporum and Rhizoctonia solani, but Citrobacter freundii and Enterobacter cloacae showed the highest antagonism. Thus, eight bacteria isolates showed multiple beneficial abilities and may be considered as promising microbial inoculants for rice plant growth and productivity.
\end{abstract}

Keywords: Bacteria, endosphere, plant growth, rice

Correspondence: potentialdoctordapo@yahoo.com, +2348077431640

\section{Introduction}

The world's population has been projected to hit 9 billion by 2050 (Ronald, 2011), and most of this growth is expected to happen in sub-Saharan Africa, particularly in Nigeria. The challenge of feeding the world's poorest people in an environmentally sustainable manner will no doubt be immense. Rice consumption is expected to increase as well. Increasing rice production worldwide will help to feed the world. Despite the 6.74 million tonnes of rice produced in Nigeria in 2014 (FAOSTAT, 2015), Nigeria has remained one of the largest importers of rice, second to Indonesia. Its importation bill of rice has increased from $\$ 1,000,000$ in the 1970 s to as high as $\$ 800$ million in 2005 (WARDA, 2007) and in 2014, Nigeria spent $\mathrm{N} 1$ billion daily importing rice (Osagie, 2014).

Among other factors, soil fertility management and biotic stresses such as pest and disease outbreaks, are limiting factors of optimal rice production in Nigeria. The use of chemical fertilizers and pesticides to remedy the problem of low soil fertility and disease outbreak is currently limited due to rising costs and environmental concerns. In order to make rice cultivation more sustainable and less dependent on chemical nitrogen and phosphorus fertilizers and pesticides, the use of endophytic plant growth-promoting bacteria (PGPB) that could protect and promote rice growth would be an alternative for rice production. (Chinnusamy et al., 2006; Cong et al., 2009; Mäder et al., 2012).

Endophytic bacteria are generally referred to as microorganisms that colonize healthy plant tissue without causing obvious symptoms or produce obvious injuries to the host (Bacon and Hinton, 2006). They are also involved in the supply of biologically 
fixed nitrogen to their host plant (Boddey et al., 2005). The beneficial effects of endophytic bacteria on plants include; the production of phytohormones, siderophores, ammonia, HCN, phosphate solubilization (Compant et al., 2005; Rajkumar et al., 2006), and the production of lytic enzymes (Nagarajkumar et al., 2004). Bacterial endophytes colonize the ecological niche similar to that of phytopathogens, which makes them suitable as biocontrol agents (Berg et al., 2005).

The use of endophytic bacteria as biofertilizer in the enhancement of rice growth and yield has been reported by Rodrigues et al. (2008) in which the inoculation of Azospirillum amazonense increased dry matter accumulation of rice grain (7 to $11.6 \%$ ), the number of panicles (3 to 18.6\%) and nitrogen accumulation at grain maturation (3.5 to $18.5 \%$ ). Azospirillum brasilense inoculum was reported to increase yield of rice up to $76 \%$ (Thakuria et al., 2004). Some of these bacteria have already been applied as biofertilizers and they are available to farmers in the developed world (Beatty and Good, 2011).

The use of endophytic bacteria as biofertilizers and biopesticides to improve rice production in Nigeria remains largely untapped despite the potential benefits of using rhizobacteria in crop production and protection. According to Abiala et al. (2015), the development of indigenous biofertlizer and biocontrol strains that suit local environments may help enhance competitiveness with in situ microorganisms and effectiveness at suppressing local pathogen strains. Also, Howell (2003) suggested that biocontrol agents should be isolated from the soil locality where they are expected to function in disease control. Thus, the present study was undertaken to isolate, identify and screen bacteria present in the endosphere of two Nigerian rice cultivars (Ofada and ITA 150) for their multiple phytobeneficial effects.

\section{MATERIALS AND METHODS}

Collection of samples and bacteria isolation

Leaf, stem and root samples of two Nigerian rice cultivars (OFADA and ITA 150) were randomly collected from the FADAMA farm of the Federal University of Agriculture, Abeokuta in triplicates. The samples collected were separately washed with tap water, followed by surface sterilization using $70 \%$ ethanol for 30 seconds, $2 \%$ Sodium hypochlorite $(\mathrm{NaOCl})$ for 5 minutes, 3\% Hydrogen peroxide for 30 seconds and then rinsed five times with distilled water. Ten grams of these samples were cut to $2-3 \mathrm{~cm}$ pieces and macerated using sterilized mortar and pestle with $12.5 \mathrm{mM}$ potassium phosphate buffer $(\mathrm{pH}$ 7.1), followed by a 10-fold serial dilution where aliquots $(100 \mu \mathrm{L})$ of the $10^{-6}$ and $10^{-8}$ dilutions were plated using the pour plate method on Nutrient Agar supplemented with cycloheximide $(100 \mu \mathrm{g} / \mathrm{mL})$ to inhibit fungal growth. Inoculated Petri plates were incubated at $28^{\circ} \mathrm{C}$ for 48 hours. After the incubation time, the colony forming units (CFU) for each plate was estimated.

Isolates differing in morphological appearance were selected and were streaked onto new plates until pure cultures were obtained. Pure cultures of bacterial isolates were maintained on NA slants and were stored at $4^{\circ} \mathrm{C}$.

\section{Cultural characterization of bacterial isolates}

The bacterial isolates were characterized based on their morphological and biochemical characteristics (Cappucino and Sherman, 2002) and examined according to the Bergey's Manual of Determinative Bacteriology (Bergey et al., 1994). Biochemical tests including catalase, citrate utilization, capsule staining, Voges-Proskaeur, Methyl red and sugar fermentation tests were carried out on the isolates.

Assays for phytobeneficial abilities of isolates Indole Acetic Acid Production

Detection of IAA production was done as described by Sharma et al. (2012). Pure bacterial isolates were inoculated in nutrient broth enriched with tryptophan $(200 \mu \mathrm{g} / \mathrm{mL})$, followed by incubation at $28^{\circ} \mathrm{C}$ for $48 \mathrm{~h}$ in a shaker incubator. $10 \mathrm{ml}$ of the resultant culture was centrifuged at $4^{\circ} \mathrm{C}$ for $10 \mathrm{~min}$ at 15,000 revolutions per minutes (rpm). Two millilitres of the supernatant was mixed with two drops of orthophosphoric acid and $4 \mathrm{ml}$ of the Salkowski's reagent ( $50 \mathrm{ml}, 35 \%$ of perchloric acid, $1 \mathrm{ml} 0.5 \mathrm{M} \mathrm{FeCl}_{3}$ solution). This mixture was kept in a dark room for 20 min, afterwards the light absorption of the mixture was estimated at $540 \mathrm{~nm}$ using a spectrophotometer. The light absorption estimates were compared to a standard curve to determine quantity of IAA produced by each isolate in $\mu \mathrm{g} / \mathrm{ml}$ This experiment was carried out in triplicates for each bacterial isolate.

\section{Phosphate solubilization}

The bacterial isolates were spot-inoculated on the Pikovskaya media containing tricalcium phosphate in a plate and incubated at $28^{\circ} \mathrm{C}$ for $72 \mathrm{~h}$ (Sharma et al., 2007). Plates were then observed for the presence of halo zones (clear zones) around the spotted colonies. The halo zone surrounding the colonies were measured, and the phosphate solubilization efficiency (PSE), expressed as a percentage according to Sharma et al. (2007).

\section{Seed Germination Bioassay}

Seedling bioassay was conducted based on the method described by Dey et al. (2004). Bacterial inocula were prepared by incubating bacterial 
cultures for $24 \mathrm{~h}$ and were diluted with sterile distilled water to give a concentration of approximately $10^{6}$ cells $/ \mathrm{mL}\left(10^{6} \mathrm{CFU} / \mathrm{mL}\right)$ adjusted with a spectrophotometer (Jenway, UK). Rice seeds (Ofada variety) were surface sterilized with $0.5 \% \mathrm{NaOCl}$ for $2 \mathrm{~min}$, followed by 30 seconds in $70 \%$ ethanol and two rinses in distilled water, followed by air drying. Seeds were coated with each bacterial isolate by immersion in a suspension of bacteria containing $10^{6} \mathrm{CFU} / \mathrm{mL}$ for 30 mins and were then dried in a laminar flow cabinet for 1 to $2 \mathrm{~h}$. Nine seeds inoculated with each bacterium were placed in 9-cm-diameter petri dishes lined with sterilized moistened filter paper and were incubated for 7 days at $28^{\circ} \mathrm{C}$. Germinated seeds were counted at day 7. Germination rate, average plumule and radical lengths as well as vigour index were calculated using the method described by the International Seed Testing Agency (1999).

\section{Ammonia Production}

The ability of each bacterial isolate to produce ammonia was assayed according to Cappucino and Sherman (1992). Bacterial isolates were tested for the production of ammonia as follows: $24 \mathrm{~h}$ old bacterial cultures were inoculated in $10 \mathrm{ml}$ nutrient broth and incubated at $30^{\circ} \mathrm{C}$ for $48 \mathrm{~h}$ in a rotator shaker. After incubation, $0.5 \mathrm{ml}$ of Nessler's reagent was added to each tube. The development of a yellow to brown colour indicated a positive reaction for ammonia production.

\section{Hydrogen Cyanide (HCN) Production}

Production of $\mathrm{HCN}$ by the isolates was detected according to the method of Ngoma et al. (2013). Nutrient broth was amended with $4.4 \mathrm{~g} / \mathrm{L}$ glycine, followed by autoclaving and pouring in Petri dishes. Each bacterial isolate was streaked on the modified agar. A Whatman filter paper soaked in 2\% Sodium carbonate in $0.5 \%$ picric acid solution was placed directly on each of the streaked agar plate. Plates were then sealed with parafilm and incubated at $28^{\circ} \mathrm{C}$ for four days. Development of orange to red colour was the indicator of $\mathrm{HCN}$ production.

\section{Antagonism assay against phytopathogenic fungi}

The antifungal activity of the bacterial isolates was assayed according to Noori and Saud (2012). Potato Dextrose Agar (PDA) was prepared, autoclaved and poured in sterile petridishes. A $5 \mathrm{~mm}$ mycelia mat of Fusarium oxysporum and Rhizoctonia solani was placed in the center of each plate. Each bacterial isolate was streaked $3 \mathrm{~cm}$ away from the fungi on both sides of the fungus and the plates incubated for $5-7$ days at $28^{\circ} \mathrm{C}$. The zone of inhibition was observed around the fungus used and the inhibition index was estimated using the formular:

$$
\text { Inhibition index }(\%)=(\mathrm{R} 1-\mathrm{R} 2) \times 100
$$

\section{$\mathrm{R} 1$}

Where R1=Radial growth of $F$. oxysporum in control plate and $\mathrm{R} 2=$ radial growth of $F$. oxysporum interacting with antagonistic bacteria. The control was a plate with the phytopathogenic fungi only. All experiments were done in triplicates.

\section{Statistical analysis}

Data obtained were analyzed using the Statistical Package for Social Sciences (SPSS) version 17.0 for Windows (SPSS, Chicago IL, USA). Data obtained were analyzed using descriptive statistics (mean and standard deviation) and Analysis of Variance (one-way) followed by post hoc pairwise comparisons using the Student-Newman-Keuls multiple-range test.

\section{Results}

Enumeration of bacterial isolates

A total of 193 bacterial strains were isolated from the endosphere of the two rice cultivars examined at $10^{8} \mathrm{CFU} / \mathrm{g}$ (Plate 1 ). The endophytic bacterial population of the roots in both rice varieties $(61.00 \pm 2.44,45.00 \pm 2.44) \mathrm{CFU} / \mathrm{g}$ were significantly higher than those of the stems $(29.33 \pm 2.44$, $32.00 \pm 2.44) \mathrm{CFU} / \mathrm{g}$ and leaves $(15.67 \pm 2.44$, $9.67 \pm 2.44$ ) in both varieties at dilution $10^{8}$ (Figure 1 ).

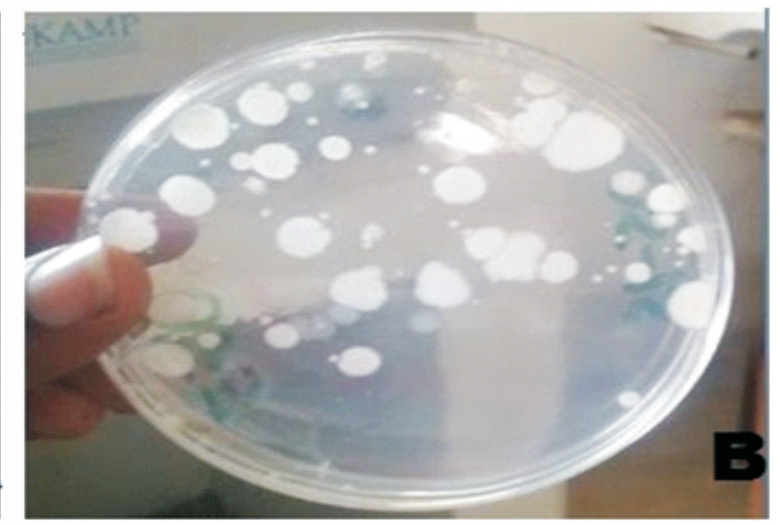

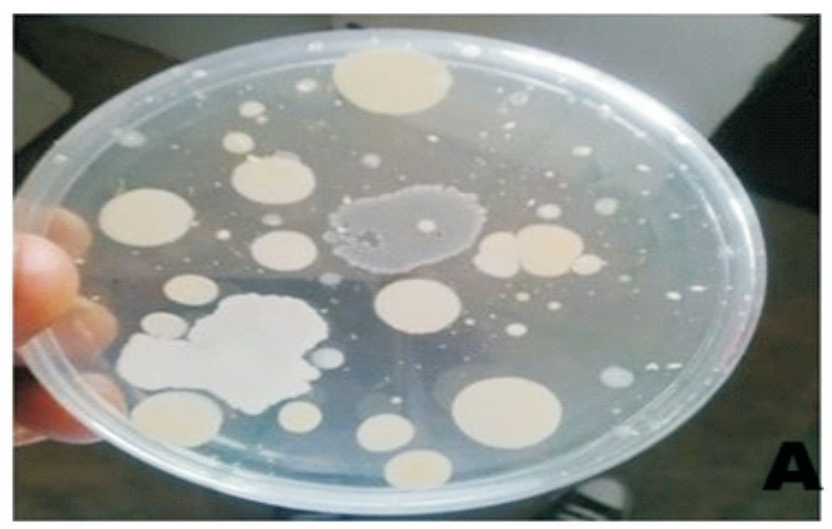

Plate 1: Bacterial colonies isolated from rice stem tissues at $10^{8}$ dilution ( $A=I T A 150$ variety, $B=O$ Ofada variety). 


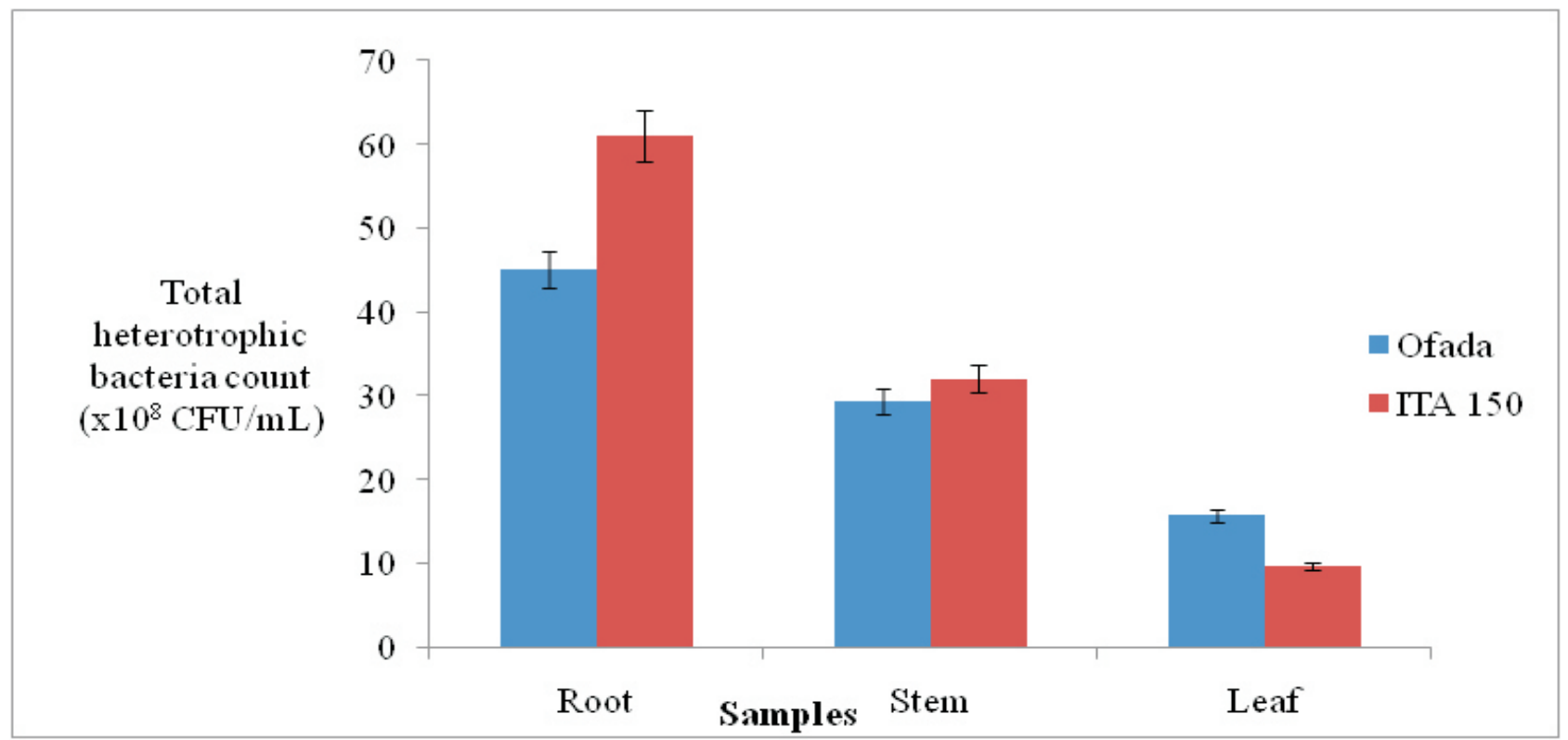

Figure 1: Comparison of the total heterotrophic bacterial count of the different samples in two different rice varieties (ITA 150 and Ofada).

Morphological and Biochemical Characteristics of Bacterial isolates

The colonial morphology of isolates was significantly diverse. All the isolates produced round shaped colonies, the elevation was either flat or raised, had smooth or undulate margin with the colony colour ranging from cream to green. Motility was observed in most isolates examined and the cell shape was mostly rod (Table 1 ). All the isolates were positive for Catalase and were Glucose fermenters. Majority of the isolates were Gram-negative in reaction (Table 2).

Table 1: Morphological characteristics of bacterial isolates

\begin{tabular}{|c|c|c|c|c|c|c|c|c|c|}
\hline $\begin{array}{l}\text { Isolate } \\
\text { code }\end{array}$ & $\begin{array}{l}\text { Rice } \\
\text { Variety }\end{array}$ & $\begin{array}{l}\text { Rice } \\
\text { plant } \\
\text { tissue }\end{array}$ & Shape & Motility & Colour & Edge & Elevation & Opacity & Size \\
\hline OP1 & $\begin{array}{l}\text { Ofada, } \\
\text { ITA150 }\end{array}$ & $\begin{array}{l}\text { Leaf } \\
\text { Root }\end{array}$ & Cocci & Motile & Cream & Undulate & Flat & Opaque & Small \\
\hline OP2 & $\begin{array}{l}\text { Ofada, } \\
\text { ITA150 }\end{array}$ & $\begin{array}{l}\text { Stem } \\
\text { Root }\end{array}$ & Rod & Motile & Cream & Undulate & Raised & Opaque & Small \\
\hline OP3 & $\begin{array}{l}\text { Ofada, } \\
\text { ITA150 }\end{array}$ & $\begin{array}{l}\text { Root } \\
\text { Root }\end{array}$ & Cocci & $\begin{array}{l}\text { Non- } \\
\text { motile }\end{array}$ & Cream & Entire & Flat & Transparent & Big \\
\hline OP4 & $\begin{array}{l}\text { Ofada, } \\
\text { ITA150 }\end{array}$ & $\begin{array}{l}\text { RSL } \\
\text { RSL }\end{array}$ & Rod & Motile & $\begin{array}{l}\text { Light } \\
\text { yellow }\end{array}$ & Entire & Flat & Opaque & Small \\
\hline OP5 & $\begin{array}{l}\text { Ofada, } \\
\text { ITA150 }\end{array}$ & $\begin{array}{l}- \\
\text { Root }\end{array}$ & Rod & $\begin{array}{l}\text { Non- } \\
\text { motile }\end{array}$ & Cream & Entire & Flat & Opaque & Big \\
\hline OP6 & $\begin{array}{l}\text { Ofada, } \\
\text { ITA150 }\end{array}$ & $\begin{array}{l}\text { RS } \\
\text { RS }\end{array}$ & Rod & $\begin{array}{l}\text { Non- } \\
\text { motile }\end{array}$ & White & Undulate & Flat & Transparent & Small \\
\hline OP7 & $\begin{array}{l}\text { Ofada, } \\
\text { ITA150 }\end{array}$ & $\begin{array}{l}\text { RSL } \\
\text { Stem }\end{array}$ & Rod & Motile & Cream & Undulate & Flat & Transparent & Big \\
\hline OP8 & $\begin{array}{l}\text { Ofada, } \\
\text { ITA150 }\end{array}$ & $\begin{array}{l}\text { Leaf } \\
\text { RS }\end{array}$ & Rod & Motile & Yellow & Entire & Flat & Opaque & Small \\
\hline
\end{tabular}

KEY: RSL-Root, Stem and Leaf, RS-Root and Stem 
Table 2: Biochemical characteristics of bacterial isolates from rice varieties

\begin{tabular}{|c|c|c|c|c|c|c|c|c|c|c|c|c|c|c|}
\hline ID & GR & $\mathrm{CA}$ & $\mathrm{CP}$ & $\mathrm{CO}$ & $\mathrm{MO}$ & $\mathrm{IN}$ & $\mathrm{CI}$ & UR & MR & $\mathrm{VP}$ & G & $\mathrm{L}$ & $\mathrm{M}$ & Suspected bacteria \\
\hline Op1 & + & + & - & - & - & - & - & - & - & + & A & - & - & $\begin{array}{l}\text { Staphylococcus } \\
\text { saprophyticus }\end{array}$ \\
\hline OP2 & - & + & - & - & + & - & - & + & + & - & A & A & A & Escherichiacoli \\
\hline OP3 & + & + & - & + & - & - & - & - & - & + & $\mathrm{A}$ & $\mathrm{A}$ & A & Staphylococcus aureus \\
\hline OP4 & + & + & + & - & + & - & + & - & - & + & A & - & $\mathrm{A}$ & Bacillus subtilis \\
\hline OP5 & - & + & - & - & + & - & + & + & + & - & - & - & - & Pseudomonas aeruginosa \\
\hline OP6 & - & + & + & - & - & - & + & + & - & + & A & A & A & Klebsiellasp \\
\hline OP7 & - & + & - & - & + & - & + & + & + & + & A & A & A & Enterobactersp \\
\hline OP8 & - & + & - & - & + & + & + & - & + & - & A & A & A & Citrobactersp \\
\hline
\end{tabular}

KEY: $\mathrm{GR}=$ Gram stain, $\mathrm{CA}=$ Catalase, $\mathrm{CP}=$ Capsule stain, $\mathrm{CO}=$ Coagulase, $\mathrm{MO}=$ Motility, $\mathrm{IN}=\mathrm{Indole}, \mathrm{CI}=$ Citrate, $U R=$ Urease, $M R=$ Methyl-red, $V P=$ Voges proskeur, $G=$ Glucose, $L=$ Lactose, $M=$ Mannitol, $A=$ Acid production, $+=$ POSITIVE, - = NEGATIVE

Assays for phytobeneficial abilities of isolates

\section{IAA production ability}

This assay was carried out on each of the 193 bacterial isolates, out of which eight isolates were positive for IAA production. A standard curve was prepared using different concentrations of pure IAA and this curve was used to compute for IAA produced by the bacterial isolates assayed. All of the eight isolates examined produced significant quantities of IAA ranging from $1 \mu \mathrm{g} / \mathrm{mL}$ produced by isolate OP8 to $32 \mu \mathrm{g} / \mathrm{mL}$ produced by isolate OP 2 . Isolates OP 8 and OP4 produced the largest quantities of IAA at 32 $\mu \mathrm{g} / \mathrm{mL}$ and $31 \mu \mathrm{g} / \mathrm{mL}$ respectively while isolates OP1 and OP2 produced the least quantities of IAA at 12 $\mu \mathrm{g} / \mathrm{mL}$ and $1 \mu \mathrm{g} / \mathrm{mL}$ respectively (Table 3 ).

\section{Phosphate solubilization}

Five isolates of the 193 endophytic bacteria were able to solubilize tricalcium phosphate with efficiencies ranging from $200 \%$ to $128 \%$, while three isolates did not solubilize the inorganic phosphate. Isolates OP4 and OP7 produced the highest phosphate solubilization efficiency of $170 \%$ as compared to isolate OP6 with $98 \%$ solubilization efficiency. Isolates OP1, OP2 and OP3 did not produce any halo zone on the Pikovskaya medium, and thus showed no phosphate solubilizing ability (Table 3 ).

\section{HCN and Ammonia production}

Only four isolates produced HCN of the 193 strains in vitro. However, the degree of $\mathrm{HCN}$ production ranged from high intensity to weak intensity. Eight bacterial isolates were positive for ammonia production (Table 3).

Antagonism assay against phytopathogenic fungus

Eight isolates inhibited Fusarium oxysporum and Rhizoctonia solani. The highest inhibition index for F. oxysporum was observed in isolate OP7 (80\% inhibition index), followed by isolate OP6 with $77.22 \%$ while isolate OP4 had the lowest inhibition index of $49.44 \%$. For $R$. solani, isolate OP8 had the greatest antifungal effect of $86.36 \%$ inhibition index, while isolate OP7 showed the least inhibition index of $48.18 \%$ (Table 3).

\section{Seed Germination Bioassay}

All isolates were examined for their effect on Ofada rice seed germination in vitro. These isolates had varying degrees of influence on the germination rate of the Ofada rice variety used. While the untreated seeds of Ofada variety (Control) had the lowest germination rate of $70.37 \%$, seeds coated with isolates OP1, OP5 and OP8 had the least germination rate of $81.48 \%$, while seeds treated with isolate OP3 had the highest germination rate of $100 \%$. The vigour index for each isolate was also computed from data obtained on the plumule and radicle lengths as well as the germination rate. It was observed that isolate OP3 had the highest vigor index of 682, while isolate OP4 had the least vigor index of 241.09. All 8 isolates assayed had significantly higher vigor index values than the control (Table 4). 
Table 3: Determination of characteristics associated with plant growth promotion of bacterial strains isolated from rice rhizosphere.

\begin{tabular}{lllllll}
\hline Isolate & IAA $(\mu \mathrm{g} / \mathrm{mL})$ & $\begin{array}{l}\text { Phosphate } \\
\text { solubilization } \\
\text { efficiency (\%) }\end{array}$ & $\begin{array}{l}\mathrm{HCN} \\
\text { production }\end{array}$ & $\begin{array}{l}\text { Ammonia } \\
\text { production }\end{array}$ & $\begin{array}{l}\text { F.oxysporum } \\
\text { inhibition } \\
\text { index (\%) }\end{array}$ & $\begin{array}{l}\text { R. solani } \\
\text { inhibition } \\
\text { index (\%) }\end{array}$ \\
\hline OP1 & $12.00 \pm 0.58^{\mathrm{c}}$ & - & - & ++ & $68.89 \pm 0.52^{\mathrm{d}}$ & $66.36 \pm 0.52^{\mathrm{b}}$ \\
OP2 & $1.00 \pm 0.58^{\mathrm{d}}$ & - & ++ & ++ & $60.55 \pm 0.52^{\mathrm{e}}$ & $64.55 \pm 0.52^{\mathrm{c}}$ \\
OP3 & $20.00 \pm 0.58^{\mathrm{b}}$ & - & - & + & $66.11 \pm 0.52^{\mathrm{d}}$ & $59.09 \pm 0.52^{\mathrm{d}}$ \\
OP4 & $31.00 \pm 0.58^{\mathrm{a}}$ & $170.00 \pm 15.00^{\mathrm{a}}$ & - & +++ & $49.44 \pm 0.52^{\mathrm{f}}$ & $64.55 \pm 0.52^{\mathrm{c}}$ \\
OP5 & $19.00 \pm 0.58^{\mathrm{e}}$ & $127.10 \pm 44.80^{\mathrm{c}}$ & + & ++ & $71.67 \pm 0.52^{\mathrm{c}}$ & $62.73 \pm 0.52^{\mathrm{c}}$ \\
OP6 & $22.00 \pm 0.58^{\mathrm{b}}$ & $98.60 \pm 3.50^{\mathrm{d}}$ & +++ & ++ & $77.22 \pm 0.52^{\mathrm{b}}$ & $60.91 \pm 0.52^{\mathrm{d}}$ \\
OP7 & $17.00 \pm 0.58^{\mathrm{c}}$ & $170.00 \pm 10.00^{\mathrm{a}}$ & - & + & $80.00 \pm 0.52^{\mathrm{a}}$ & $48.18 \pm 0.52^{\mathrm{e}}$ \\
OP8 & $32.00 \pm 0.58^{\mathrm{a}}$ & $153.30 \pm 27.80^{\mathrm{b}}$ & +++ & + & $63.33 \pm 0.52^{\mathrm{e}}$ & $86.36 \pm 0.52^{\mathrm{a}}$ \\
\hline
\end{tabular}

KEY:- $=$ not detected. $+=$ low. $++=$ medium.$+++=$ high. Values are mean \pm standard error of mean. Values followed by different letters within a column indicates significant differences according to the Student-NewmanKeuls multiple-range test $(a=0.05)$

Table 4: Beneficial effects of identified bacterial isolates on Ofada seed germination and vigor index

\begin{tabular}{lclll}
\hline Isolates & $\begin{array}{c}\text { Germination Rate } \\
(\mathrm{cm})\end{array}$ & $\begin{array}{c}\text { Mean Plumule } \\
\text { length }(\mathrm{cm})\end{array}$ & $\begin{array}{c}\text { Mean Radicle } \\
\text { length }(\mathrm{cm})\end{array}$ & Vigor Index \\
\hline Control & $70.37 \pm 1.67 \mathrm{~d}$ & $1.1 \pm 0.55 \mathrm{~d}$ & $0.9 \pm 0.57 \mathrm{e}$ & $140.74 \pm 27.35 \mathrm{e}$ \\
OP1 & $81.48 \pm 2.94 \mathrm{c}$ & $1.63 \pm 0.12 \mathrm{c}$ & $1.45 \pm 0.13 \mathrm{~d}$ & $250.96 \pm 10.84 \mathrm{~d}$ \\
OP2 & $96.29 \pm 4.00 \mathrm{~b}$ & $2.3 \pm 0.85 \mathrm{~b}$ & $2.61 \pm 0.18 \mathrm{~b}$ & $472.78 \pm 41.31 \mathrm{c}$ \\
OP3 & $100 \pm 5.00 \mathrm{a}$ & $3.91 \pm 0.20 \mathrm{a}$ & $2.91 \pm 0.51 \mathrm{~b}$ & $682.00 \pm 71.53 \mathrm{a}$ \\
OP4 & $85.19 \pm 8.01 \mathrm{c}$ & $1.38 \pm 0.16 \mathrm{~d}$ & $1.45 \pm 0.00 \mathrm{~d}$ & $241.09 \pm 4.81 \mathrm{~d}$ \\
OP5 & $81.48 \pm 2.94 \mathrm{c}$ & $1.72 \pm 0.04 \mathrm{c}$ & $1.58 \pm 0.16 \mathrm{~d}$ & $268.88 \pm 8.03 \mathrm{~d}$ \\
OP6 & $96.29 \pm 4.00 \mathrm{~b}$ & $2.34 \pm 0.09 \mathrm{~b}$ & $2.61 \pm 0.18 \mathrm{~b}$ & $476.64 \pm 30.51 \mathrm{c}$ \\
OP7 & $96.29 \pm 4.00 \mathrm{~b}$ & $2.63 \pm 0.04 \mathrm{~b}$ & $3.78 \pm 0.38 \mathrm{a}$ & $617.22 \pm 22.13 \mathrm{~b}$ \\
OP8 & $81.48 \pm 2.94 \mathrm{c}$ & $1.8 \pm 0.30 \mathrm{c}$ & $1.85 \pm 0.85 \mathrm{c}$ & $297.40 \pm 49.37 \mathrm{~d}$ \\
\hline
\end{tabular}

Values are mean \pm standard error of mean. Values followed by different letters within a column indicates significant differences according to the Student-Newman-Keuls multiple-range test $(a=0.05)$ 


\section{Discussion}

The use of microorganisms and the exploitation of beneficial plant-microbe interactions offer promising and environmentally friendly strategies for conventional and organic agriculture worldwide (Berg, 2009). Various endophytic bacteria that inhabit plant tissues can aid in sustainable agriculture.

In this study, the endophytic bacterial population was observed to be highest in the roots, followed by the stems and lowest in the leaves of both rice cultivars examined. This can be attributed to the greater concentration of nutrients (exudates) present in the root region as compared to the phyllosphere. According to Bacilio-Jiménez et al. (2003), the root exudates produced by rice plants promote the interaction between endophytic bacteria and root tissues. These results are similar to endophytic bacteria isolated from rice landraces (Rangjaroen et al., 2015), the cultivated rice cultivar Khao Dawk Mali 105 (Prakamhang et al., 2009) and wild rice cultivars Oryza rufipogos, $O$. nivara and $O$. granulata (Koomnok et al., 2007).

Based on the morphology and biochemical characteristics of the isolated bacterial species, 8 distinct bacteria morphotypes were tentatively identified as Bacillus subtilis, Pseudomonas aeruginosa, Klebsiella sp, Enterobacter sp, Citrobacter sp, Staphylococcus aureus, Staphylococcus saprophyticus and Escherichia coli. The species identified in this study are in correlation with other studies on rice endopshere microbiome (Mbai et al., 2013, Mwajita et al., 2013) who both implicated a wide variety of bacteria.

The plant growth-promoting abilities of the isolated endophytic bacteria were assayed with varying results observed. Endophytes have been shown to promote plant growth by producing IAA (Mendes et al., 2007). Indole acetic acid (IAA) is a key phytohormone known for its ability to elongate and enlarge plant root cells in order to permit greater nutrient and water absorption. In this study, eight out of 193 endophytic bacterial isolates produced IAA in concentrations. The range of IAA produced in this study is similar to a report by Ji et al. (2014) who observed an IAA range of 3.1-24.6 $\mu \mathrm{g} / \mathrm{mL}$ while lower range of IAA produced was reported by Rangjaroen et al. (2015).

Phosphorus, an essential plant macronutrient, although present in significant quantities in soils is not readily available for plant uptake due to its insoluble forms being dominant. Of the 193 strains, only 5 isolates solubilized inorganic phosphate by producing halo zones on the Pikovskaya medium. The phosphate solubilization efficiency
(PSE) recorded ranged from $98 \%$ to $128 \%$. The range of PSE recorded is similar to a report by Kaushal and Kaushal (2011). The ability of bacteria to solubilize insoluble phosphates has been attributed to their capacity to reduce $\mathrm{pH}$ by the excretion of organic acids during the assimilation of ammonia (Gyaneshwar et al., 1999).

The production of hydrogen cyanide ( $\mathrm{HCN})$ and ammonia, secondary metabolites by certain plant-associated bacteria is another beneficial trait of a PGPB. HCN produced can inhibit the growth and metabolism of potential plant pathogen and thus protect the plant from harm as well as strengthen the host's disease resistance mechanism (Whipps, 2001). Ammonia can also have inhibitory effects on certain phytopathogens such as Fusarium oxysporum, F. oxysporum $\mathrm{f}$. sp. melongenae and Macrophomina phaseolina (Yildiz et al., 2012). In this study, only four out of the 193 bacterial strains were able to produce $\mathrm{HCN}$ as Citrobacter sp and Klebsiella sp produced the highest colour intensities and thus the highest HCN while eight endophytic bacteria produced $\mathrm{NH} 3$, as observed by the change in colouration of the broth medium.

This study investigated the effectiveness of bacterial isolates whether they could increase the seed germination rate as well as other plant growth parameters of the seedlings in vitro (plumule and radicle lengths). Eight isolates significantly increased the growth parameters of the inoculated rice seeds as compared to the uninoculated control. This could be attributed to the suppression of seed pathogens (Abiala et al., 2015) as well as the synthesis of hormones such as IAA by the isolates in this study $(\mathrm{Ng}$ et al., 2012). Indole acetic acid (IAA) can trigger the activity of specific enzymes that promote early germination and increased plumule and radicle length and seed inoculation with IAA producing rhizobacteria has been shown to enhance early seedling establishment (Khalid et al., 2004).

The unique ability of certain plant associated bacteria to control and inhibit the growth of plant pathogens is of utmost importance in selecting for potentially plant beneficial bacteria. In this study, eight bacteria were able to inhibit the growth of two soil-borne fungal pathogens Rhizoctonia solani and Fusarium oxysporum. Enterobacter sp (86.36\%) showed the highest antagonism to Rhizoctonia solani. Fusarium oxysporum was also highly inhibited by Citrobacter sp (80\%). The differential rates of fungal inhibition by the bacteria species suggests that the mode of action and types of antifungal metabolites produced vary from one bacterium to another (Williams and Asher, 1996). The reduction of fungal growth by certain plant beneficial bacteria and the in vitro inhibition zones may be probably due to 
antifungal substances (such as Zwittermycine-A, kanosmine, lipopeptides) and/or lytic enzymes released by these isolates (Noumavo et al., 2015).

The results obtained from the various assays indicates that endophytic bacterial isolates OP4, OP7 and OP8 corresponding to Bacillus subtilis, Enterobacter sp and Citrobacter sp showed the best abilities to promote plant growth in vitro as seen by the results of the various assays conducted.

\section{References}

Abiala, M.A., Odebode, A.C., Hsu, S.F. and Blackwood, C.B. (2015). Phytobeneficial properties of bacteria isolated from the rhizosphere of maize in Southwestern Nigerian soils. Appl Environ Microbiol. $81: 4736$.

Bacilio-Jiménez, M., Aguilar-Flores, S., VenturaZapata, E., Pérez-Campos, E., Bouquelet, S. and Zenteno, E. (2003). Chemical characterization of root exudates from rice (Oryza sativa) and their effects on the chemotactic response of endophytic bacteria. Plant Soil. 249:271-277

Bacon, C.W. and Hinton, D.M. (2006). Bacterial Endophytes: The Endophytic Niche, its occupants, and its utility. Springer. pp. 155-194.

Beatty, P.H. and Good, A.G. (2011). Future prospects for cereals that fix nitrogen. Science 333: 416-417.

Berg, G. (2009). Plant-microbe interactions promoting plant growth and health: perspectives for controlled use of microorganisms in agriculture. Appl Microbiol Biotechnol. 84: 11-18

Berg, G., Krechel, A., Ditz, M., Sikora, R.A., Ulrich, A. and Hallmann, J. (2005). Endophytic and ectophytic potato-associated bacterial communities differ in structure and antagonistic function against plant pathogenic fungi. FEMS Microbiol Lett. 51: 215-229.

Bergey, D.H., Holt, J.G. and Noel, R.K. (1994). Bergey's Manual of Systematic Bacteriology, 19th Ed Baltimore. Williams \& Wilkins. p 1935.

Boddey, R.M., de Oliveira, C., Urquiaga, S., Reis, V.M., de Olivares, F.L., Baldani, V.L. and Dobereiner, J. (2005). Biological nitrogen fixation associated with sugarcane and rice: Contributions and Prospects for improvement. Plant Soil. 174: 195-209.

Cappuccino, J.G. and Sherman, N. (1992). Biochemical activities of microorganisms: Microbiology, A Laboratory Manual. The Benjamin/Cummings Publishing Co. pp 1245.
Cappuccino, J.G. and Sherman, N. (2002). Microbiology: A laboratory manual. New York: Pearson Education Incorporated.

Compant, S., Reiter, B., Sessitsch, A., Nowak, J., Clément, C. and Barka, E.A. (2005). Endophytic colonization of Vitis vinifera L. by plant growthpromoting bacterium Burkholderia sp. strain PsJN. Appl Environ Microbiol. 71: 1685-1693.

Cong, P.T., Dung. T.D., Hien, T.M., Hien, N.T., Choudhury, A.A., Kecskés, M.L. and Kennedy, I.R. (2009). Inoculant plant growth-promoting microorganisms enhance utilisation of urea- $\mathrm{N}$ and grain yield of paddy rice in southern Vietnam. Eur J Soil Biol. 45:52. doi:10.1016/j.ejsobi.2008.06.006

Dey, R., Pall, K.K., Bhatt, D.M. and Chauhan, S.M. (2004) Growth promotion and yield enhancement of peanut (Arachis hypogaea L.) by application of plant growth-promoting rhizobacteria. Microbiol Res. 159:371. doi:10.1016/j.micres.2004.08.004

FAOSTAT (2015) FAO Statistical data. http://faostat3.fao.org/download/Q/QC/E

Gyaneshwar, P., Parekh, L.J., Archana, G., Poole, P.S., Collins, M.D., Hutson, R.A. and Kumar, G.N. (1999). Involvement of a phosphate-starvation inducible glucose dehydrogenase in soil phosphate solubilization by Enterobacter asburiae. FEMS Microbiology Lett. 171: 223-229.

Howell, C.R. (2003). Mechanisms employed by Trichoderma spp. in the biological control of plant diseases: the history and evolution of current concepts. Plant Dis. 87:4-10. http://dx.doi.org/10.1094/PDIS.2003.87.1.4.

International Seed Testing Agency (1999). International rules for seed testing. Seed Sci Technol. 27: 333.

Ji, H.S., Gururani, A.M. and Chun, S. (2014). Isolation and characterization of plant growth promoting endophytic diazotrophic bacteria from Korean rice cultivars. Microbiol Res. 169(1): 83-98.

Kaushal, M. and Kaushal, R, (2011). Screening and characterization of rhizobacterial strains of Bacillus spp isolated from rhizosphere of Cauliflower (Brassica oleracea var botrytis L.). Afr J Microbiol Res. 7(17): 1657-1663.

Khalid, A., Arshad, M. and Zahir, Z. A. (2004). Screening plant growth-promoting rhizobacteria for improving growth and yield of wheat. J App Microbiol. 
96: 473-480.

Koomnok, C., Teaumroong, N, Rerkasem, B. and Lumyong, S. (2007). Diazotroph endophytic bacteria in cultivated and wild rice in Thailand. Science Asia 33:429-435.

Mäder, P., Kaiser, F., Adholeya, A., Singh, R. and Uppal, H.S. (2012). Inoculation of root microorganisms for sustainable wheat-rice and wheat-black gram rotations in India. Soil Biol Biochem.43:609.

Mbai, F.N., Magiri, E.N., Matiru, V.N., Ng'ang'a, J. and Nyambati, V.S. (2013). Isolation and Characterisation of Bacterial Root Endophytes with Potential to Enhance Plant Growth from Kenyan Basmati Rice. Am Int J Contemp Res. 3: 25-40.

Mendes, R., Pizzirani-Kleiner, A.A., Araujo, W.L. and Raaijmakers, J.M. (2007). Diversity of cultivated endophytic bacteria from sugarcane: genetic and biochemical characterization of Burkholderia cepacia complex isolates. Appl Environ. Microbiol. 73: 7259-7267.

Mwajita, M.R., Muraje, H., Tani, A. and Kahangi, M.E. (2013). Evaluation of rhizosphere, rhizoplane and phyllosphere bacteria and fungi isolated from rice in Kenya for plant growth promoters. SpringerPlus 2: 606-615.

Nagarajkumar, M., Bhaskaran, R. and Velazhahan, R. (2004). Involvement of secondary metabolites and extracellular lytic enzymes produced by Pseudomonas fluorescens in inhibition of Rhizoctonia solani, the rice sheath blight pathogen. Microbiol. Res. 159:73-81.

Ng, L.C., Sariah, M., Sariam, O., Radziah, O. and Zainal-Abidin, M.A. (2012). Rice seed bacterization for promoting germination and seedling growth under aerobic cultivation system. Aus. J. Crop Sci. $6: 170-175$.

Ngoma, L., Esau, B. and Babalola, O.O. (2013). Isolation and characterization of beneficial indigenous endophytic bacteria for plant growth-promoting activity in Molelwane Farm, Mafikeng, South Africa. Afri J Biotechnol. 12:4105. doi:10.5897/ajb2013.12345.

Noori, M.S. and Saud, H.M. (2012). Potential plant growth-promoting activity of Pseudomonas $\mathrm{sp}$ isolated from paddy soil in Malaysia as biocontrol agent. J PIt Path Microbiol. 3:120-127. doi: 10.4172/2157-7471.1000120

Noumavo PA, Agbodjato NA, Gachomo, E.W., Salami,
H.A., Farid, B.M., Adjanohoun, A., Kotchoni, S.O. and Lamine, B.M. (2015). Metabolic and biofungicidal properties of maize rhizobacteria for growth promotion and plant disease resistance. Afr J Biotechnol. 14(9): 811-819.

Osagie, C. (2014). Rice Import Ban and Trade Politics. THISDAY Newspaper (JAN 28, 2014) mtaisong, K., Boonkerd, N. and Teaumroong, N. (2009). The communities of endophytic diazotrophic bacteria in cultivated rice (Oryza sativa L.). Appl Soil Ecol. 42:141-149.

Rahman, M, Ano, T. and Shoda, M. (2007). Biofilm fermentation of iturin $A$ by a recombinant strain of Bacillus subtilis 168. J Biotechnol. 127: 503-507.

Rajkumar, M., Nagendran, R., Lee, K.J., Lee, W.H. and Kim, S.Z. (2006). Influence of plant growth promoting bacteria and $\mathrm{Cr} 6+$ on the growth of Indian mustard. Chemosphere. 62:741-748

Rangjaroen, C., Rerkasem, B., Teaumroong, N., Noisangiam, R. and Lumyong, S. (2015). Promoting plant growth in a commercial rice cultivar by endophytic diazotrophic bacteria isolated from rice landraces. Ann Microbiol. 65:253-266 DOI 10.1007/s13213-014-0857-4

Rodrigues, E.P., Rodrigues, L.S., Oliveira, A.L., Baldani, V.L., Teixeira, K.R., Urquiaga, S. and Reis, V.M. (2008). Azospirillum amazonense inoculation: effects on growth, yield and N2 fixation of rice (Oryza sativa L.). Plant Soil. 302: 249-261.

Ronald, P. (2011) Plant genetics, Sustainable Agriculture and Global Food Security. Genetics 188:11-20.

Sharma, K., Dak, G., Agrawal, A., Bhatnagar, M. and Sharma, R. (2007). Effect of phosphate solubilizing bacteria on the germination of Cicer arietinum seeds and seedling growth. J Herb Med Toxicol. 1: 61-67. doi: $10.13140 /$ RG.2.1.4824.0162

Sharma, T., Navin, K. and Nishan, R. (2012). Isolation, screening and characterization of PGPR isolates from rhizosphere of rice plants in Kashipur region (Tarai region). J Biotechnol Int. 5(3): 69-84.

Thakuria, D., Talukdar, N.C., Goswami, C., Hazarika, S., Boro, R.C. and Khan, M.R. (2004). Characterization and screening of bacteria from rhizosphere of rice grown in acidic soils of Assam. Current Science. 86: 978-985.

Wani, P.A., Khan, M.S. and Zaidi, A. (2007). Effect of metal tolerant plant growth-promoting 
Bradyrhizobium sp. (vigna) on growth, symbiosis, seed yield and metal uptake by green gram plants. Chemosphere. 70: 36-45.

Whipps, J.M. (2001). Microbial interactions and biocontrol in the rhizosphere. J Exp Bot. 52: 487-511.

Williams, G.E. and Asher, M.C. (1996). Selection of rhizobacteria for the control of Phytium ultimum and Aphanomyces cochiliodes on sugarbeet seedlings. Crop Protection. 15: 479-486.

Yildiz, H.N., Handan, H.A. and Dikilitas, M. (2012). Screening of rhizobacteria against Fusarium oxysporum f. sp. Melongenae; the causal agent of wilt disease of eggplant. African J Microbiol Res. 6(15): 3700-3706. 